\title{
PTPN7 Gene
}

National Cancer Institute

\section{Source}

National Cancer Institute. PTPN7 Gene. NCI Thesaurus. Code C24709.

This gene plays a role in regulation of lymphocyte development and suppression of signal transduction. 